\title{
Should bodychecking be allowed in minor hockey?
}

\author{
W. James King, Claire M.A. LeBlanc
}

$\infty$

See related article page $\mathrm{I} 55$

W ith more than 4.5 million Canadians involved in ice hockey as coaches, officials, administrators, volunteers or spectators, and more than 500000 registered players, hockey is undeniably Canada's national sport. ${ }^{1}$ Combining skill and speed, hockey is an exciting sport for both players and spectators. Hockey can also be an emotional, intense game and is classified as a collision sport by the American Academy of Pediatrics because of the intentional body contact, or bodychecking. ${ }^{2}$

Unlike body contact, which may be an incidental part of the game, bodychecking is defined as an individual defensive tactic designed to legally separate the puck carrier from the puck. Using this tactic, a defensive player is allowed to deliberately and forcefully "hit" another player who is carrying the puck. Body contact, on the other hand, is an individual defensive tactic designed to legally block or impede the progress of a puck carrier. ${ }^{3}$ Using this tactic, a defensive player is not allowed to "hit' an opponent but can use his or her body to block the opponent's way or take away the skating lane by proper skating, angling and positioning. Hockey Canada, the governing body for amateur hockey in Canada, recommends that both tactics be taught as part of a 4-step skills-development program, with body contact being taught before bodychecking. ${ }^{3}$

Every year numerous children are injured severely enough while playing hockey to attend an emergency department, with 2002/03 estimates of more than 3000 children I6 years of age and younger with such injuries in Ontario alone. ${ }^{4}$ This is likely the tip of the iceberg, since many injuries, particularly concussions, which may have long-term consequences on the developing brain, are underreported. ${ }^{5,6}$ Bodychecking has been identified as the main cause of injury, accounting for $50 \%-86 \%$ of all injuries in minor hockey, despite the fact that the vast majority of players participate in leagues where bodychecking is not allowed. ${ }^{7,8}$ One reason for these injuries is the potential for considerable size differences, up to $53 \mathrm{~kg}$ in weight and $55 \mathrm{~cm}$ in height, among puberty-aged players. ${ }^{8}$

Although these injuries are viewed by some as an unfortunate part of a fast and dangerous game, they should not be seen as an inevitable consequence of participation in sport. Nor should a single tactic or skill be allowed to place young children at increased risk of injury. Two expert panels already recommend that bodychecking be limited among young players. The American Academy of Pediatrics' Committee on Sports and Fitness recommends that bodychecking be limited until at least 15 years of age. The Canadian Academy of Sports Medicine recommends that it be eliminated from all levels of minor hockey that are not designed as training for professional and international ranks.,

Despite the known injury risk and expert recommendations, Hockey Canada allows 9 of its 13 branches to start teaching bodychecking at the Peewee level (ages II and I2) and 3 at the Atom level (ages 9 and ro) in an "experimental" fashion. ${ }^{3}$ However, one branch, representing Quebec, does not teach bodychecking until the Bantam level (ages I3 and I4). The 3 branches that allow bodychecking at the Atom level have been directed to conduct research on bodychecking, including injury rates. Previous research commissioned by Hockey Canada purporting no increased risk of injury from bodychecking was used in the decision to lower the age for bodychecking; however, the results and conclusion of this research have been questioned. ${ }^{10}$ Although there has been considerable debate, some hockey experts believe that the risk of injury is overstated, that hitting is part of the game and that learning to bodycheck at a young age will have a protective effect to avoid injury in later years.

\section{More than 3000 children I6 years and younger visited emergency departments with hockey-related injuries} in Ontario in 2002/03.

In this issue (see page I55) Hagel and colleagues looked at the effect of bodychecking on young children by taking advantage of a change in Hockey Canada's minor hockey age groupings during the 2002/03 season. ${ }^{11}$ Specifically, they were able to look at the injury rates among II-year-old children before and after the introduction of bodychecking in that age group and compare this information with injury trends among I0- and I2-year-old children. What they found is consistent with a growing body of evidence: among the IIyear-old children, the rate of injuries, including severe injuries, increased significantly (rate ratio I.9, 95\% confidence interval I.4-2.4) after bodychecking was introduced; little change was observed in the other age groups. This study is significant because it contributes more evidence from a population perspective that bodychecking in minor hockey places children at increased risk of injury. These results are also supported by a recent study from a hospital perspective 
by Macpherson and colleagues that identified a similar increased risk. ${ }^{12}$

In their study, Macpherson and colleagues compared the number of injuries reported in regions where bodychecking was allowed with those in regions where bodychecking was not allowed. Among players aged ro to I3 who were in bodychecking leagues, there was a significant increase in the risk of injury requiring a visit to the emergency department. They also found evidence among older players that there is no protective effect from learning to bodycheck at a younger age. Although it is difficult to prove a conclusive cause-and-effect relationship from retrospective studies, both were carefully conceived, relied on established databases with proven validity and were consistent in their findings.

To place the risk of injury identified in these studies into context, one needs to consider the length of exposure to bodychecking for an II-year-old Peewee player at a competitive level. The average amount of ice time during a game for this child to be exposed to bodychecking is only 12 minutes. In a single season the child will face at least a 2-fold increased risk of serious injury (including the risk of fracture), for a combined total of 6 hours of playing time (based on 50 games per season, including the regular season, tournaments and playoffs).

Development of young players is a cornerstone of the game. Hockey Canada's mission statement reads "Lead, develop, and promote positive hockey experiences." ${ }^{13}$ Hockey Canada also believes in a positive hockey experience for all participants, in a safe, sportsmanlike environment. However, does allowing bodychecking in minor hockey promote a safe environment? Not according to the evidence presented here. It is clear that bodychecking increases the risk of injury at least 2-fold and does not appear to confer a protective effect from injury in later years.

What should be done to further decrease the risk of injury? Changes in equipment, education about good sportsmanship and proper enforcement of rules are important and have been successful in decreasing — but not eradicating - the risk of injury. On the basis of the best available evidence and expert opinion in child development and injury prevention, bodychecking should be eliminated from minor hockey programs. Body contact should be taught in a progressive manner to players in Atom, Peewee and Bantam levels. Body- checking should be limited to those players who require such skill in preparation for professional programs and are mature enough to make an informed decision regarding the risk of participation. Research should continue to focus on identifying the best evidence for further injury reduction.

This article has been peer reviewed.

Jim King is Chief, Division of Pediatric Medicine, Department of Pediatrics, and Claire LeBlanc is Head of Rheumatology and Sport Medicine, Department of Pediatrics, University of Ottawa, Ottawa, Ont.

Competing interests: None declared.

Contributors: Both authors made substantial contributions to the conception, drafting and revision of the article for important intellectual content and gave final approval of the version to be published.

\section{REFERENCES}

I. Hockey Canada. About Hockey Canada. Available: www.hockeycanada.ca/index cfm/ci_id/6698/la_id/I.htm (accessed 2006 May 3I).

2. Committee on Sports Medicine and Fitness, American Academy of Pediatrics. Safety in youth ice hockey: the effects of body checking. Pediatrics 2000;105:657-8.

3. Hockey Canada. Background on checking. Available: www.hockeycanada.ca/6/8/6 /2/indexi.shtml (accessed 2006 May 31).

4. Canadian Institute for Health Information. Hockey injuries in Ontario [press release]. Ottawa: The Institute; 2003 July 28. Available: http://secure.cihi.ca/cihiweb /dispPage.jsp?cw_page=media_28jul2003_e (accessed 2006 May 3I).

5. Marchie A, Cusimano MD. Bodychecking and concussions in ice hockey: Should our youth pay the price? $C M A J$ 2003; 169 (2):124-8.

6. Williamson IJ, Goodman D. Converging evidence for the under-reporting of concussions in youth ice hockey. BrJ Sports Med 2006;40:128-32.

7. Benson BW, Meeuwisse WH. Ice hockey injuries. In: Maffulli N, Caine DJ, editors. Epidemiology of pediatric sports injuries: team sports. Basel: Karger; 2005. p. 62-95.

8. Brust JD, Leonard BJ, Pheley A, et al. Children's ice hockey injuries. Am J Dis Child I992;I46:74I-7.

9. Canadian Academy of Sport Medicine Safety Committee. Violence and injuries in ice hockey [position statement]. Ottawa: The Academy; I988. Available: www .casm-acms.org/forms/statements/HockeyViolEng.pdf (accessed 2006 May 3I).

Io. Montelpare MJ, McPherson MN. Measuring the effects of initiating body checking at the Atom age level. In: Pearsall DJ, Ashare AB, editors. Safety in ice hockey; fourth volume. West Conshohocken (PA): American Society for Testing and Materials; 2004. p. 70-84.

II. Hagel BE, Marko J, Dryden D, et al. Effect of bodychecking on injury rates among minor ice hockey players. $C M A J$ 2006;175(2):155-60.

I2. Macpherson A, Rothman L, Howard A. Body-checking rules and childhood injuries in ice hockey. Pediatrics 2006;117:143-7.

I3. Hockey Canada. Mandate and mission. Available: www.hockeycanada.ca/6/8/3/6 /indexi.shtml (accessed 2006 May 31).

Correspondence to: Dr. W. James King, Division of Pediatric Medicine, Department of Pediatrics, Children's Hospital of Eastern Ontario, 40I Smyth Rd., Ottawa ON KIH 8LI; king@cheo.on.ca

\section{ACCESS}

$C M A J$ is the only leading general medical journal that is free online. CMAJ.ca receives over 2 million hits per month of which two-thirds are from international readers. 